http://kitaibelia.unideb.hu/

ISSN 2064-4507 (Online) • ISSN 1219-9672 (Print)

(C) 2015, Department of Botany, University of Debrecen, Hungary

20 (1): 38-43.; 2015

DOI: $10.17542 /$ kit.20.38

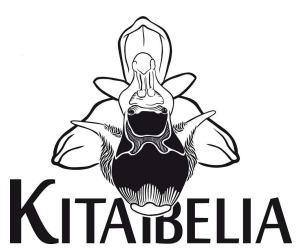

\title{
Az Asparagus verticillatus L. Magyarországon
}

\author{
WIRTH Tamás ${ }^{1 *} \&$ GYERGYÁK Kinga ${ }^{2}$
}

(1) Pécsi Tudományegyetem TTK Biológiai Intézet, Ökológiai Tanszék, H-7624 Pécs, Ifjúság útja 6. *tamaswirth@gmail.com

(2) Pécsi Tudományegyetem ÁOK Farmakognóziai Tanszék, H-7624 Pécs, Rókus utca. 2.

\section{Asparagus verticillatus L. in Hungary}

Abstract - Climbing asparagus (Asparagus verticillatus L.) a new adventive species to the Hungarian flora was recently discovered in the city of Pécs (South Hungary) in 2011-2012. Taxonomy, morphological description and current localities of the species are presented in this paper. $A$. verticillatus is a mediterranean-submediterranean species native in Balkan Peninsula, Eastern Europe, Western- and Middle Asia. The species is a popular ornamental plant in Hungary, but no data was available about its escape or naturalisation in the country so far. Herbarium specimens from Hungary were collected so far mostly from botanical and private gardens; only one specimen was collected in a dry grassland along a roadside in the city, respectively. The newly discovered small populations are located mostly in secondary dry grasslands, at the edges of vineyards and private gardens on the southern slopes of the Mecsek Mts and only one specimen was found far from the residential area in natural vegetation. Because climbing asparagus is a frequently planted ornamental plant in several locations of Pécs, further escape, naturalisation and persistence of the species is possible in the future.

Keywords: alien species, Asparagaceae, climbing asparagus, floristics, South Hungary

Összefoglalás - Pécs közigazgatási területének finomléptékű flóratérképezése során az Asparagus verticillatus L. kivadult egyedeit találtuk meg a város több pontján 2011-2012 során. A dolgozat áttekintést nyújt a faj taxonómiájáról, morfológiai jellemzéséről és magyarországi előfordulásáról. Az örvös spárga mediterrán-szubmediterrán faj, mely a Balkán-félszigeten, Kelet-Európában, valamint Nyugat- és Közép-Ázsiában őshonos. Magyarországon kedvelt dísznövény; kiszökéséről, illetve elvadulásáról azonban eddig nem volt információnk. Korábbi gyűjtési adatai botanikus kertekből, kertekből származnak, illetve egy példány került elő Pécsett útszéli száraz gyepből. A most megtalált egyedek főleg a városnak a Mecsek déli oldalára felkúszó részén, kiskertes és szőlőtermő területein élnek, de egy példány előkerült a lakott területtől távolabbi, természetközeli vegetációból is. Mivel a fajt a város több pontján is ültetik, további kiszökésére, elvadulására, valamint tartós fennmaradására a jövőben is számíthatunk.

Kulcsszavak: adventív faj, Asparagaceae, florisztika, örvös spárga, Dél-Magyarország 


\section{Bevezetés}

A spárga (Asparagus) nemzetség fajai közül Magyarországon két taxon előfordulását jelzi a szakirodalom. Az A. officinalis L. (közönséges spárga) száraz gyepekben, cserjésekben és erdőkben (ritkán ligeterdőkben, mocsárréteken és szikeseken) az egész ország területén szórványosan megtalálható, őshonosnak tartott, illetve termesztett faj; míg az A. tenuifolius Lam.-nak (vékonylevelű spárga) néhány korábbi kétes adata ismert a Balaton környékéről (Badacsony, Baladonendréd) (Soó 1973, MESTERHÁzY \& KIRÁLY 2009). Ez utóbbi faj adatai Soó (1973) szerint az A. officinalis var. pseudotenuifolius Polgár-ra vonatkoznak. Pécs finom léptékű flóratérképezése során a hazai flórára új $A$. verticillatus L. [örvös spárga (PRISZTER 1998)] több egyede került elő sövények mellől, szőlők közti rézsűkről, falak tövéből, illetve melegkedvelő tölgyesből.

\section{Taxonómia}

Az Asparagus verticillatus L. az Asparagaceae család Asparagoideae alcsalád Asparagus nemzetség Asparagus alnemzetségébe tartozik (KomARov 1968, CASTRo et al. 2013). A Linné által leírt fajt a szakirodalom számos néven említi: Asparagus buxbaumius Gueldenst. ex Ledeb., A. scandens Gueldenst. ex Ledeb., A. tricarinatus K. Koch, A. tricarinatus Redouté, $A$. verticillaris Lam., A. verticillatum L. (KomARov 1968, [1], [2]). Infraspecifikus taxonok közül a var. triphyllus Bresler-t és a var. floribundus Baker-t tartják számon, melyek közül napjainkban az előbbit az $A$. bresleranus Schult. \& Schult. f., míg az utóbbit az A. verticillatus L. subsp. floribundus (Baker) K. Richt. szinonímjaként használják [1]. A Flora Europaea (TUTIN 2000) és számos más munka (KoMARov 1968, DAVIS 1984, TownSEND \& GUEST 1985, RECHInger et al. 1990, GovaERTS 1995, TAKHTAJAn 2006) az Asparagus verticillatus L. nevet fogadja el.

\section{Morfológiai jellemzés, elterjedés}

Az Asparagus nemzetség tagjai évelő, földalatti rizómával rendelkező fajok. Száruk elágazó, leveleik pikkelyszerű képletekké alakultak, a fotoszintézist a levélágak végzik. A valódi levelek gyakran viselnek sarkantyúszerű, éles képletet. A levélágak tű alakúak, az áttetsző, pikkelyszerű valódi levelek hónaljában csoportosulnak. Virágaik a pikkelyszerű levél maradványok hónaljában erednek, számuk (1-)2 vagy a fölötti, általában egyivarúak, a lepel hattagú; a virágok 6 darab porzóval és háromrekeszű termővel rendelkeznek; termésük piros vagy fekete színű bogyó.

A hazánk flórájára új $A$. verticillatus alaktani jellemzése KomARov (1968) és TuTiN (2000) nyomán: Nagytermetű, 75-250 cm magas, tövénél kissé fásodó, lágyszárú évelő növény. Hajtásai felállók, bordásak, elágazók, csúcsuk felé gyakran visszahajlanak; a levélágak berzedten szétállnak, számuk az idősebb hajtásokon akár 20 is lehet, a fiatalabb hajtásokon általában 1-3; (10-)20-50(-60) mm hosszúak és 0,5-1,2 mm szélesek; erősen háromélűek, fényesek, szélükön papillásak lehetnek. A pikkelylevelek sarkantyúszerű tüskével rendelkeznek. A virágok a levélágak tövében erednek, számuk (1-)2-10(-20), a kocsányok 1,5-5 mm hosszúak. A virág 3-4 mm, a lepellevelek 2-3,5 mm hosszúak. A lepel zöld, csak a lepelcimpák csúcsa fehéres. A bogyó piros, 5,5-8 mm átmérőjű, 1-3 maggal (1. ábra). A faj júniusban virágzik. 


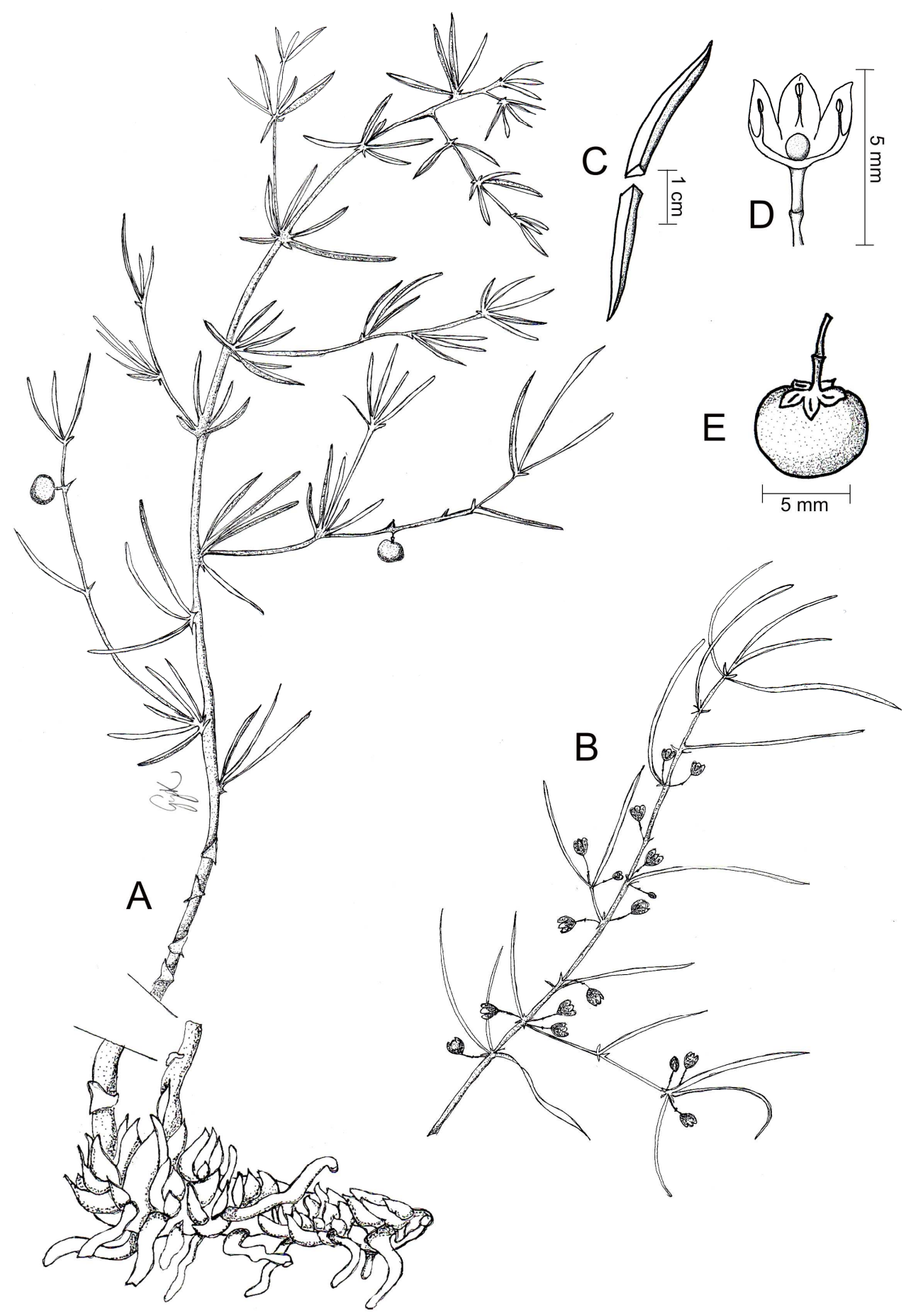

1.ábra. Asparagus verticillatus (A - habitus, B - virágzó hajtás, C - levélág keresztmetszet, D - porzós virág, $\mathrm{E}$ - termés) (Gyergyák K. rajza).

Fig. 1. Asparagus verticillatus (A - habit, B - flowering stem, C - transverse section of the cladode, D male flower, E - fruit) (drawn by K. Gyergyák). 
Az örvös spárga a hasonló, közel rokon, dísz- és gyógynövényként is termesztett $A$. cochinchinensis (Loureiro) P. J. Merill-től rövidebb és erősen háromélű levélágai, több és nagyobb méretű virágai, valamint piros színű termései alapján könnyen megkülönböztethető.

Az A. verticillatus beillesztését a hazai Asparagus kulcsba (MESTERHÁzY \& KIRÁLY 2009) a következőképpen javasoljuk:

1a A szár ágas, sima, felálló. A levélágak 3-8(-15) tagú örvökben; 0,5-5 cm hosszúak, 0,3-0,4 mm szélesek; hengeresek, felszínük sima. A virágok 1-2(-3)-asával állnak. A lepel 4,5-6,5 mm hosszú, sárgás- v. zöldesfehér. A portok 0,7-1,6 mm hosszú. A bogyó 6-10 mm átmérőjű, piros. T: 30-150 cm. Ge. V-VII. Száraz (gyakran zavart) gyepek, mezsgyék, erdőszélek. Ősi zöldségnövény, kultúrváltozatait termesztik. M. e. t. szórv.

A. officinalis L. - Közönséges spárga

1b A szár ágas, finoman bordázott, felálló, csúcsa felé visszahajló. A levélágak 1-3(-20) tagú örvökben; (1-)2-5(-6) cm hosszúak, 0,5-1,2 mm szélesek; erősen háromélűek, felszínük sima, az élek mentén papillásak lehetnek. A virágok (1-)2-10(-20)-asával állnak. A lepel 23,5 mm hosszú, zöld, csúcsa fehéres. A portok 0,4-0,6 mm hosszú. A bogyó 5,5-8 mm átmérőjű, piros. T: 75-250 cm. Ge. VI. Adv. (Balkán-fsz., K-Európa, Kaukázus, Ny- és KözépÁzsia). Kertekben ültetik, kiszökik és elvadul: falak töve; száraz gyepek, mezsgyék, erdőszélek. DDt (Pécs) igen ritka.

A. verticillatus L. - Örvös spárga

Az örvös spárga a mediterrán-szubmediterrán régióban erdőszegélyeken, cserjésekben, sziklás termőhelyeken fordul elő; pontusi-keleti-turáni flóraelem. Őshonos Azerbajdzsánban, Bulgáriában, Görögországban, Grúziában, Irakban, Iránban, Macedóniában, Romániában, Oroszországban (Kaukázus), Örményországban, Szerbiában, Törökországban, Türkmenisztánban és Ukrajnában (КUвотA et al. 2012, TUTiN 2000, ZLATKOvić et al. 2011). Szerbiában ZlatKović et al. (2011) a fajt a sebezhető kategóriába sorolja és javasolja a felvételét a Szerb Flóra Vörös Könyvébe.

Bár széleskörűen alkalmazott dísznövény és magjait több internetes kertészeti portál is árulja, Európa többi országából nincs információnk a taxon kivadulásáról.

\section{Hazai előfordulás}

A faj kedvelt kerti dísznövény, melyet Pécs több pontján is ültetnek. Az ország területéről származó korábbi gyűjtései is kertekben ültetett példányokat dokumentálnak, két példány található az MTM Növénytár (BP) Adventív- és kultúrflóra gyűjteményében, illetve egy a PTE TTK Herbáriumában (JPU). Kivadulva először 2007. 10. 07-én gyűjtötte Pécsett BALOGH Lajos a Francia-emlékműhöz vezető út egyik kanyarulatában. A most megtalált egyedek többsége a város belterületéről került elő sövények, szőlők közti rézsúk és falak tövéből, csupán egyetlen példány nőtt lakott területtől távolabb a Pécs-Somogyhoz tartozó Kakukk-hegyen melegkedvelő tölgyesben. A megtalált populációkból herbáriumi példányt gyűjtöttünk, amelyet a PTE TTK Herbáriumában (JPU) helyeztünk el.

A megtalált egyedek főleg a városnak a Mecsek déli oldalára felkúszó részén, kiskertes és szőlőtermő területein élnek, de egy példány előkerült a lakott területtől távolabbi, természetközeli vegetációból is. Mivel Pécs (és az ország, WIRTH ined.) több pontján is ültetett dísznövény, a faj további kiszökésére, elvadulására, valamint tartós fennmaradására a jövőben is számíthatunk. 
Az Asparagus verticillatus magyarországi adatai:

\section{Herbáriumi adatok}

- Budapest: „Botanikus kert” (Csapody Vera in BP 323785, 1967. 10. 20.)

- Budapest: „Botanikus kert” (Csapody Vera in BP 301222, 1968. 09. 11.)

- Rózsafa: „falusi előkertben” (Vöröss László Zsigmond in JPU, 1962. 08. 11.)

Aktuális előfordulási adatok

- Pécs: „a Francia-emlékműhöz vezető út egyik kanyarjában, gyepűben (BALOGH L. ex verbis)" [9975.1] - Későbbi alapos terepbejárás során nem került elő a faj, valószínűleg a területen folyó korábbi építkezési, területrendezési munkálatok során megsemmisült az állomány.

- Pécs: „Felsőhavi utca 70. előtt a fal tövében fiatal egyedek és idősebb példány”; „Losonc utca 42. előtt járdarepedésben egy fiatal egyed”; „Magaslati út 56. előtti sövény aljában idős egyed”; „Mária dűlő 92. és 94. kertjei közötti kerítés mentén több idősebb példány” [9975.1]; „Gyükés, a Szt. Bertalan kápolnától ÉNy-ra kertek közötti rézsűben két idősebb példány” [9875.3]; „Pécs-Somogy mellett, a Kakukkhegy dél-keleti oldalán melegkedvelő tölgyesben, a csúcshoz közel egy idősebb példány" [9875.4].

\section{Köszönetnyilvánítás}

Szeretnénk köszönetet mondani Barina Zoltánnak és Pifkó Dánielnek az MTM Növénytár vonatkozó anyagának rendelkezésre bocsátásáért, Csiky Jánosnak a kézirat áttekintéséért. Továbbá köszönjük Balogh Lajosnak korábbi adata közlésének átengedését.

\section{Irodalom}

Castro P., Gil J., Cabrera A. \& Moreno R. (2013): Assessment of genetic diversity and phylogenetic relationships in Asparagus species related to Asparagus officinalis. - Genetic Resources and Crop Evolution 60: 1275-1288.

Davis P. H. (ed.) (1984): Flora of Turkey and the East Aegean Islands 8. - Edinburgh University Press, Edinburgh, $632 \mathrm{pp}$.

GovaerTS, R. (1995): World Checklist of Seed Plants 1(1, 2). - MIM, Deurne, 483 pp., 529 pp.

Komarov V. L. (1968): Asparagus L. - In: Komarov V. L. (ed.), Flora of the U.S.S.R. Vol. IV. Israel Program for Scientific Translations, Jerusalem, pp. 325-339.

Kubota S., Konno I. \& Kanno A. (2012): Molecular phylogeny of the genus Asparagus (Asparagaceae) explains interspecific crossability between the garden asparagus (A. officinalis) and other Asparagus species. - Theoretical and Applied Genetics 124: 345-354.

MESTERHÁZY A. \& KiRÁLY G. (2009): Asparagaceae. - In: KiRÁLY G. (szerk.), Új magyar füvészkönyv. Magyarország hajtásos növényei. Határozókulcsok. Aggteleki Nemzeti Park Igazgatóság, Jósvafő, p. 481.

PriszTER Sz. (1998): Növényneveink. A magyar és a tudományos növénynevek szótára. - Mezőgazda Kiadó, Budapest, $549 \mathrm{pp}$.

Rechinger K.H., Browicz K., Persson K. \& Wendelbo P. (1990): Flora Iranica 165. - Naturhistorisches Museum Wien, $194 \mathrm{pp}$.

Soó R. (1973): A magyar flóra és vegetáció rendszertani-növényföldrajzi kézikönyve V. - Akadémiai Kiadó, Budapest, 723 pp.

Takhtajan A. L. (ed.) (2006): Conspectus Florae Caucasi 2. - Editio Universitatis Petropolitanae, 466 pp.

Townsend C. C. \& Guest E. (eds) (1985): Flora of Iraq 8. - Ministry of Agriculture \& Agrarian Reform, Baghdad, $440 \mathrm{pp}$.

Tutin T. G. (2000): Asparagus L. - In: Tutin T. G. et al. (eds), Flora Europaea 5. Cambridge University Press, Cambridge, pp. 71-73.

Zlatković B., RANĐELOVIĆ V., LAKuŠić D. \& Stefanović V. (2011): Novelties for the vascular flora of Serbia. Botanica Serbica 35: 103-110. 
WIRTH \& GYERGYÁK (2015) - Kitaibelia 20 (1): 38-43.

\section{Hivatkozott világháló oldalak}

[1] The Plant List (2013): Version 1.1. Published on the Internet; http://www.theplantlist.org/ (Hozzáférés: 2014. 11. 01.)

[2] Tropicos.org (2014): Missouri Botanical Garden http://www.tropicos.org/Name/100150358 (Hozzáférés: 2014. 11. 01.)

Beérkezett / received: 2014. 11. 16. • Elfogadva / accepted: 2015. 02. 03. 